\title{
LAW AND INVESTMENT IN PALAU: A BRIEF OVERVIEW FOR PROSPECTIVE FOREIGN INVESTORS
}

\author{
Colin P.A. Jones*
}

\section{INTRODUCTION}

The Republic of Palau ${ }^{1}$ (ROP) is an island nation located in the Northern Pacific, roughly between Guam and the Philippines. With a population of approximately 18,000 , it is one of the world's smallest and newest independent nations, ${ }^{2}$ yet it has acquired the status of a highly-regarded tourist destination and is considered one of the world's great diving locations. ${ }^{3}$ In addition to being a premier diving destination, Palau's unspoiled beauty and rich marine environment, especially the unique Rock Islands (which include the famous Jellyfish Lake, a marine lake populated by the only non-stinging jellyfish in the world), have ensured Palau a small but steady stream of tourist visitors. The popular reality television program "Survivor" recently featured Palau, ${ }^{4}$ indicating that tourism is a trend that can be expected to continue and expand. Palau's rich marine resources also provide it with an additional basis for economic development.

Currently, a core element of Palau's economy is the approximately $\$ 20$ million in aid the country receives annually from the United States. ${ }^{5}$ This aid funds much of Palau's government, which is the country's main employer, and accounts for a significant portion of Palau's $\$ 5000$ per capita GNP. ${ }^{6}$ Since the aid is scheduled to terminate in 2009 , the country is seeking new avenues of

*Associate Professor, Doshisha University Law School (Kyoto). The author is a member of the bars of New York, Guam, and Palau, and is deeply grateful for the comments and other assistance in writing this article received from Jerry Marugg, Palauan lawyer and past president of the Palau Bar Association. For Akiko, with love.

1. "Belau" in the Palauan language. THE BOOK OF RULE: HOW THE WORLD Is GOVERNED 286 (Dorling Kindersly, Ltd. 2004) [hereinafter THE BOOK OF RULE].

2. EASt West CTR., BanK of Haw., Republic of Palau ECONOMic Report APRII 2003, at 3 (2003). Palau became an independent nation in 1994. Id.

3. NeIL M. LEVY, MoON HANDBOOKS, Micronesia HANDBOoK 150 (5th ed. 2003).

4. See, e.g., CBS Broad., Inc., Meet 'Survivor: Palau' Cast, (Jan. 13, 2005) http://www.cbsnews.com/stories/2005/01/13/earlyshow/series/survivor/main666612.shtml?CMP =ILC-SearchStories.

5. Richard Paddock, Palau Is Going to Have to Learn to Say No, SEATtLE Times, Apr. 14, 2006, at A3.

6. THE BOOK OF RULE, supra note 1, at 286. See also GEOGRAPHICA's POCKET WORLD REFERENCE 540 (Laurel Glen 2000). More recent accounts give Palau a per capita income of $\$ 6870$, "one of the highest in the Pacific Ocean region." Neighbors Seduced by Oceans of Cash, Seattle Times, Apr. 14, 2006, at A3. 
development to maintain, if not improve, its current economic situation. ${ }^{7}$

A combination of factors makes Palau an interesting study: it is a small nation using its legal system to foster economic development through foreign investment while simultaneously preserving its cultural and economic heritage from domination by foreign interests. The purpose of this Article is to provide a brief overview of some of the salient features of Palau's legal system that may be of interest to prospective investors, focusing on the country's Foreign Investment Act. ${ }^{8}$

\section{HISTORY}

Palau is a group of islands in the Micronesian region of the Pacific Ocean southeast of the Philippines. It is believed to have been inhabited for several thousand years, but it had limited contact with European countries until the islands were declared a part of Spain's Pacific empire in the late 19th century. ${ }^{9}$ Spain then sold the islands, along with most of its other Micronesian possessions, to Germany during the course of peace negotiations with America following its victory in the Spanish-American war of 1898. This resulted in the United States assuming dominion over the Philippines and Guam. ${ }^{10}$ Germany's presence in the Pacific only lasted until World War I, when the League of Nations awarded Japan a mandate over Palau and most of the other German possessions in Micronesia. Palau and most of Micronesia effectively became a Japanese colony, referred to as the Nan'yo, and remained such until the end of World War II. ${ }^{11}$

Palau assumed a central importance in the Japanese mandate, and Koror,

7. Paddock, supra note 5, at A3.

8. Foreign Investment Act, 28 P.N.C. $\S$ 101-21.

9. THE BOOK OF RULE, supra note 1, at 286. Palau's first significant encounter with the West was probably in 1783 when a British ship hit a reef near the Rock Islands. The ship's crew spent several months with the Palauans, who helped them build a new ship. When the British departed, Lebuu, the son of High Chief Ibedul, went with them to England where he attended school, but died of smallpox a few months after arrival. Smallpox was an unfortunate result of Western contact with Palau, which had lost up to ninety percent of its population to the disease by the end of the 19th century. Elizabeth Basset, Palau, http://www.mnsu.edu/emuseum/cultural/oldworld/pacific/palau.html. See also NANCY BARBOUR, PALAU 35-36 (Mitchell P. Warner ed., 1995).

10. Office of Court Counsel, Supreme Court of THe Republic of Palau, The Quest FOR HARMONY A PICTORIAL HISTORY OF LAW AND JUSTICE IN THE REPUBLIC OF PALAU 9 (1995) [hereinafter THE QUEST FOR HARMONY].

11. For a history of Japanese involvement in Micronesia, see generally MARK PEATTIE, NAN'Yo: THE RISE AND FALl OF THE JAPANESE IN MiCRONESIA, 1885-1945 (1988). For a discussion of the German empire in the Pacific, see DIRK H.R. SPENNEMAN, AURORA AusTRALIS; The German Period In The Mariana Islands (1999), Rudolf von BenNigsen, The GeRman anNeXation of the Caroline, Palau \& Mariana IslandS (Dirk. Spennemann trans., 2003). Hermann Joseph Hiery, The Neglected War: The German South Pacific and the INFLUENCE OF WORLD WAR I (1995). While it is not uncommon for writers to refer to them as being part of the "South Pacific," Palau and most of the other Micronesian islands are located above the Equator. 
Palau's previous capital, became the administrative center of Japan's empire in Micronesia. $^{12}$ In addition, a pre-war Japanese government policy of encouraging Japanese citizens to migrate to the Nan'yo rendered Palau's indigenous people a minority population by the eve of World War II. ${ }^{13}$ As a result, a noticeable Japanese influence is evident in Palau today despite decades of post-war American influence. For example, first and last names of Japanese origin abound among Palauans, and Japanese is an official language of Angaur, one of Palau's island states. ${ }^{14}$ The Palauan words for utilities, which the Japanese introduced, such as telephones and electricity, are derived from their Japanese terms. The tochi daicho, a land survey conducted by the Japanese in the 1930s, is still referenced in land disputes as evidence of historical claims of ownership, and knowledge of its significance is critical to understanding modern Palauan property law and passing the Palau bar exam. ${ }^{15}$ The Palauan courthouse, the national legislature building, and several other government buildings were originally built by the former Japanese government. ${ }^{16}$

Palau suffered heavily in World War II, particularly the islands of Peleliu and Angaur, which are now states. The civilian populations of the islands were completely evacuated, and the islands became the scenes of prolonged and bloody amphibious battles when they were invaded by U.S. forces in the fall of 1944. ${ }^{17}$ Even today, Palauan courts accord less evidentiary value to tochi daicho listings for land in Peleliu and Angaur than in other states, partially due to the destruction and population displacement suffered by the two islands during the war. ${ }^{18}$

With Japan's defeat in World War II, Palau and many of Japan's other island possessions became part of the United Nations-mandated "Trust

12. PEATTIE, supra note 11 , at 170 . In fall of 2006 , as mandated in Article XIII, Section 11 of the Palauan Constitution, the constitution the capital was relocated to the Northern island of Badeldaob. See, e.g., Mike Leidemann, Pride in Palau for New Capitol, The HonOlulu ADVERTISER (Nov. 12, 2006), available http://the.honoluluadvertiser.com/article/2006/Nov/12/il/FP611120310.html (last visited January 16, 2007).

13. PEATTIE, supra note 11 , at 157-60.

14. CIA World Factbook, http://www.cia.gov/cia/publications/factbook/geos/ps.html (last visited Oct. 30, 2006).

15. PEATTIE, supra note 11, at 96-100. Although the bar exam in Palau includes a local law essay component that includes questions regarding the tochi daicho and other unique aspects of the country's legal system, it otherwise relies completely on the multi-state bar examination components used throughout the United States.

16. See, e.g., ARNold H. Leibowitz, Embattled ISLANd Palau's Struggle for INDEPENDENCE 112 (1996).

17. See Jim Moran \& Gordon Rottman, Peleliu 1944 The Forgotten Corner of Hell 15 (2002). For an excellent study of the Micronesian experience of the Pacific War, see LIN Poyer, Suzanne Falgout, Laurence Marshall CaruCCI, The TyphoON of War (2001).

18. See, e.g. Orak v. Temael, 10 ROP 105 (2003). "A listing of ownership in the Tochi Daicho is presumed to be accurate, and a party seeing [sic] to rebut that listing must present the Land Court with 'especially clear and convincing evidence."' Id. at 108 (citing Llecholch v. Lawrence, 8 ROP Intrm 24, 24 (1999)). See also PEATTIE, supra note 11, at 298. 
Territory of the Pacific Islands" (TTPI), which was administered by the United States until Palau's formation as an independent nation. ${ }^{19}$ The United States and the U.N. Security Council administered TTPI under a trusteeship agreement. $^{20}$ The agreement gave the United States a broad scope of authority, including full powers of administration, legislation, and jurisdiction over the entire territory, as well as the right (currently not exercised) to maintain military bases and close off certain areas for security reasons. The TTPI was initially administered by the U.S. Navy, which established a system of courts and other governmental institutions. ${ }^{21}$ In 1951, administrative responsibility for the TTPI shifted to the U.S. Department of the Interior. ${ }^{22}$ Palau adopted its constitution in 1981 and became independent in 1994, though it remains heavily dependent upon the United States for aid, uses the American dollar as its currency, and has a United States zip code (96940). ${ }^{23}$

\section{CONSTITUTION, GOVERNMENT, AND SOURCES OF LAW}

Despite its small size and population, Palau uses a federal system with sixteen states whose national government retain all powers not expressly delegated to the individual state governments by the Constitution of the Republic of Palau. ${ }^{24}$ The national government is comprised of an executive, legislative, and judicial branch. The Executive branch is headed by an elected president who serves for a maximum of two four-year terms. ${ }^{25}$ The president is assisted by a vice president and advised by a Council of Chiefs from each of the states regarding "matters concerning traditional laws, customs and their relationship to this Constitution and the laws of Palau."26

19. Saipan, Tinian, Rota, and the other Marianas islands combined to form the Commonwealth of the Northern Mariana Islands (a U.S. territory). The Caroline Islands (including Chuk, Pohnpei, Yap, and Kosrae) formed the Federated States of Micronesia, and the Marshall Islands became the Republic of the Marshall Islands. THE BOOK OF RULE, supra note 1 , at 155, 284.

20. Robert J. Stewart, The Legal System of Micronesia, in MODERN LEGAL SYSTEMS CYCLOPEDIA VOLUME 2 \& 2.120 .14 (Kenneth R. Redden ed., 1989).

21. THE QUEST FOR HARMONY, supra note 10, at 22-32.

22. Id. at $33-45$.

23. THE BOOK OF RULE, supra note 1, at 286 . One of the reasons for the significant lag between the adoption of a constitution and actual independence was the difficulty in resolving the conflict between the new constitution's ban of nuclear and other weapons of mass destruction in Palau and the use of Palauan territory by the U.S. military envisioned in the Compact of Free Association between Palau and the United States. Since the implementation of the Compact was effectively a precondition to Palauan independence, resolution of this conflict, and independence, required a prolonged process including several plebiscites as well as a constitutional amendment. See THE QUEST FOR HARMONY, supra note 10, at 74-79. See also CONST. OF THE REPUblic OF PALAU art. XIII, § 6, amend. 1. See also The Compact of Free Association, 48 U.S.C. $\$ \S 1931-1962$ (2006).

24. CONST. OF THE REPUBLIC OF PALAU art. XI, $\$ 2$.

25. Id. art. VIII.

26. Id. art. VIII, $\S \S 2,6$. 
The legislative branch, the Olbiil Era Kelulau (OEK), is a bicameral body comprised of the House of Delegates, to which each state elects a representative, and the Senate, which is elected based on proportional representation. $^{27}$ The OEK is vested with a broad range of legislative powers similar to those of the U.S. Congress, including the power of impeachment and a catch-all powers granted by a U.S.-style "necessary and proper" clause. ${ }^{28}$

Under the Palauan constitution, the judiciary consists of a Supreme Court, a National Court, and other courts of limited jurisdiction that the OEK may establish." The judicial power extends to "all matters in law and equity." 30 With the National Court currently inactive, the principal court of general jurisdiction is the Supreme Court, which consists of a trial division and an appellate division. ${ }^{31}$ Since the same justices serve in both divisions, the constitution prohibits a justice from sitting on an appellate panel hearing a case at which he or she presided over at the trial level. ${ }^{32}$ The president, the vice president, and all members of the OEK must be Palauan citizens and reside in Palau for at least five years prior to election; however, the constitution requires that members of the judiciary only be "admitted to practice law before the highest court of a state or country in which he is admitted to practice for at least five (5) years preceding his appointment."33 This reflects Palau's continuing need to import trained legal professionals for the judiciary and other government positions requiring legal expertise; the country does not have a university, let alone a law school. Justices of the Palauan Supreme Court hold their respective offices "during good behavior" and are appointed by a judicial nominating commission comprised of the chief justice, members of the bar, and Palauan citizens selected by the president. ${ }^{34}$

The ROP constitution appears to have been modeled after the U.S. Constitution. The federal structure and constitutional provisions for the separation of power among the three branches of government will be quite familiar to a lawyer trained in the United States. Similarly, the fundamental rights enumerated in Article IV of the ROP Constitution correspond roughly to those contained in the U.S. Bill of Rights, with the notable exception of the second amendment: Palau's Constitution specifically denies any individual the right to possess firearms. ${ }^{35}$ At the same time, however, Palau's constitutional drafters also learned from the American experience; the Constitution deals

27. Id. art. IX.

28. Id. art. IX, $\$ 5$.

29. Id. art. $\mathrm{X}$.

30. Id. art. $\mathrm{X}, \S 5$.

31. Office of Court Counsel, Supreme Court of the Republic of Palau, The Wisdom

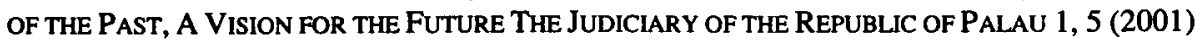
[hereinafter THE WISDOM OF THE PAST].

32. CONST. OF THE REPUBLIC OF PALAU art. X, § 2.

33. Id. art. $\mathrm{X}, \& 8$.

34. Id. art. $\mathrm{X}, \S \S 7,9$.

35. Id. art. IV; art. XIII, §§ 12-13. 
clearly with issues that have been the subject of serious constitutional debate in the United States. For example, while the Constitution forbids the creation of a national religion, it specifically permits government support for parochial schools on a non-discriminatory basis for non-religious purposes. ${ }^{36}$ Also, while the federal government is prohibited from most types of discrimination, it is specifically allowed to accord preferential treatment to citizens of Palau and to enact discriminatory laws and policies where such are necessary "for the protection of minors, elderly, indigent, physically or mentally handicapped and other similar groups, and in matters concerning intestate succession and domestic relations." 37

A number of sources of law other than the Constitution exist in Palau. Statutory sources include the Palauan National Code (PNC), which contains the post-independence national legislation, state legislation, as well as the TTPI-era Palau District Code and Trust Territory Code. ${ }^{38}$ Because of its long history as a de facto U.S. territory, Palau remains heavily dependent upon the United States as a source of law and a source of legal professionals. As a result, Palau's judiciary is comprised of lawyers trained in the United States, including nonPalauan nationals. ${ }^{39}$ American-trained lawyers also serve in other branches of the Palauan government.

Another sign of Palau's dependence upon the United States within the legal sphere is its almost wholesale adoption of U.S. common law principles. This is accomplished through a provision in the PNC stating that, in the absence of otherwise applicable statutory or customary law, "[t]he rules of the common law, as expressed in the restatements of the law approved by the American Law Institute and, to the extent not so expressed, as generally understood and applied in the United States, shall be the rules of decision in the courts of the Republic." ${ }^{40}$ In addition to common law rules, Palau's courts

36. Id. art. IV, § 1 .

37. Id. art. IV, $\S 5$.

38. Stewart, supra note 20 , at $\S 2.180 .4, \S 1.4(B)$. The constitution specifies that laws predating it remain in force until repealed, revoked, amended, or expired. CONST. OF THE REPUBLIC OF PALAU art. XV, \& 3(a).

39. See, e.g., THE WISDOM OF THE PAST, supra note 31 , at $46-51$. The practical need to import legal professionals is suggested by the fact that while Palauan citizenship is a requirement for eligibility for the presidency, the vice-presidency, or a seat in either house of the national legislature, it is not required for appointment to the judiciary. CONST. OFTHE REPUBLIC OF PALAU art. VIII, § 3 (executive branch eligibility requirements); art. IX, § 6 (legislative branch); art. X, $\S 8$ (judicial branch). As noted in a recent Palau Supreme Court publication, all of the justices of the Supreme Court combined with most, if not all, court counsel were trained in the United States. See THE WISDOM OF THE PAST, supra note 31, at 7-10, 15.

40. 1 P.N.C. $\S 303$ (emphasis added). This provision leaves open the question of which common law principles to apply when different U.S. jurisdictions apply different rules. When faced with various possible applicable principles, Palauan judges have apparent discretion to choose the principle most suitable. The Supreme Court of Palau has specifically held that title 1, section 303, of the Palauan National Code does not require that a common law rule have been adopted in a majority of U.S. jurisdictions before it can be considered applicable law in Palau. See, e.g., Renguul v. Airai State Publ. Lands Auth., 8 ROP Intrm. 282 (2001). 
look to U.S. case law on the American Constitution and federal statutes as a reference for interpreting comparable provisions of Palauan law. ${ }^{41}$

Palau's courts, however, do not slavishly follow U.S. law. Rather, it only serves as a primary reference tool when local law is uncertain. For example, the appellate division of the Supreme Court has held that Anglo-Saxon concepts of land ownership, such as tenancies in common, fail "to fit within the Palauan framework of property law" and thus, may not be presumed to exist by a trial court. ${ }^{42}$

Palau's constitution also preserves an important role for custom by providing that "statutes and traditional law shall be equally authoritative.",43 Furthermore, in the event of conflicts between a statute and a traditional law, "the statute shall prevail only to the extent it is not in conflict with the underlying principles of the traditional law."44 Traditional law, rooted in custom, must be proved by "clear and convincing evidence, often through the testimony of expert witnesses.",45

Lineage, clan affiliation, and status within a clan are important in Palau. For example, title to land may be held in the name of a clan, which has discretion to manage clan assets in accordance with custom. ${ }^{46}$ Furthermore, significant determinations, such as the disposition of an intestate decedent's assets and the selection of the bearer of traditional clan titles, may also be made primarily based upon clan custom. ${ }^{47}$ While the Palauan courts may recognize and apply the existence of traditional laws in such spheres, once a custom is recognized as being applicable, such recognition also requires the court to defer to those claiming to act in accordance with such custom. ${ }^{48}$ Prospective $^{2}$

41. Silmai v. ROP, 10 ROP 139 (2003). "Because Palau's Excessive Fines Clause is derived from a comparable clause in the United States Constitution, we have found it appropriate to consider U.S. case law in construing it." Id. See also Sedang v. Ongeshii, 10 ROP 100 (2003). "Because ROP Rule of Civil Procedure 60(b) is derived from the Federal Rules, it is appropriate to look to United States authorities for guidance." Id.

42. Smau v. Emilian, 6 ROP Intrm. 31, 36 (1996).

43. CONST. OF THE REPUBLIC OF PALAU art. V, § 2.

44. Id.

45. THE WISDOM OF THE PAST, supra note 31, at 3. See also, e.g., Yangilmau v. Carlos, 7 ROP Intrm. 169 (1995). "Customary law must be proven by clear and convincing evidence, usually through the testimony of expert witnesses." $l d$.

46. Ngeribongel v. Gulibert, 8 ROP Intrm 68 (2001). "It is Paluan custom that the management and distribution of assets within a clan is primarily a private matter in which the clan is entitled to exercise a wide discretion..." Id. Such traditions include the eldecheduch, a gathering at which the disposition of a decedent's property is decided by his clan. This institution has been formalized to an extent in Palau's inheritance statute, which provides that in the absence of a will, land owned in fee simple by a decedent will generally be disposed of "in accordance with the desires of the immediate maternal or paternal lineage to whom the deceased was related by birth or adoption and which was actively and primarily responsible for the deceased prior to his death." See 25 P.N.C. \& 301(b).

47. 25 P.N.C. $\$ 301(b)$.

48. See, e.g., Filibert v. Ngirmang, 8 ROP Intrm. 273, 277 (2001) (“Although the courts have constitutional authority over matters presenting issues of customary law . . . customary matters are best resolved by the parties involved rather than the courts."). "It cannot be disputed 
investors need to be aware of the possibility of conflicting claims arising in transactions involving land or other assets that may be owned by a clan rather than an individual.

\section{CONSTITUTIONAL PROVISIONS RELEVANT TO FOREIGN INVESTORS}

As noted above, Palau's constitution is clearly modeled on the U.S. Constitution. However, it also contains a number of provisions that are designed to protect Palau's people and customs from being overwhelmed by outside influences. Prospective foreign investors should be cognizant of these provisions.

Of particular note is, Article III, which defines Palauan citizenship as accruing to a person born of at least one parent who is a citizens of Palau. ${ }^{49}$ Citizenship is a key prerequisite to the enjoyment of a number of fundamental rights under Palau's constitution. ${ }^{50}$ For example, while Palau's Constitution does contain a provision similar to the U.S. Constitution's "contracts clause," it only protects "contracts to which a citizen is a party" from impairment by legislation. ${ }^{51}$ Thus, foreign investors need to be aware of the possibility that privately negotiated contracts may be subject to post-facto interference by action of the national or state legislatures, a risk which is hardly unique to Palau. $^{52}$ Furthermore, while the constitution prohibits governmental discrimination based on a number of categories, it contains a specific exception for the preferential treatment of citizens. ${ }^{53}$

Citizenship is also a key part of another constitutional provision that will affect the structuring of many investments in Palau: "[o]nly citizens of Palau and corporations wholly owned by citizens of Palau may acquire title to land or water in Palau." 54 It is thus impossible for foreigners or even companies with

that, in Palauan custom, a decision of a council of chiefs to accept or reject the ourrot's choice of title holder is final and not subject to outside review..." Matlab v. Melimarang, 9 ROP 93 (2002). "Ourrot" is a title which reflects some of the matriarchal aspects of Palauan society. A "senior ourrout" is generally the oldest female of a maternal line of a clan, and may play a significant role in choosing male holders of traditional titles.

49. CONST. OF THE REPUBLIC OF PALAU art. III, \& 2.

50. The present constitution prohibits Palauans from having dual citizenship after the age of twenty-one. Id. art. III, §§ 1, 3. In 2004, however, a proposed constitutional amendment allowing dual citizenship was approved and may come into force if the requisite vote (a majority of votes and three-fourths of the states) is met in the next general election. Id. art. XIV, § 1(a). See also Donald R. Shuster, Micronesia in Review: Issues and Events, 1 July 2004 - 30 June, 2005 Palau, 18 CONTEMP. PAC. 114, 116 (2006). added).

51. U.S. CONST. art. I, $\S 10$; CONST. OF THE REPUblic OF PALAU art. IV, § 6 (emphasis

52. To the extent that the protection the Palauan constitution provides to contract rights extends to acts of the national legislature, it is arguably more extensive in at least one respect than the U.S. Constitution, in that the contract clause only applies to states. See U.S. ConST. art I, § 10 .

53. CONST. OF THE REPUBLIC OF PALAU art. IV, § 5.

54. Id. art. XIII, \& 8. 
minority foreign ownership to obtain and maintain title to land in Palau. ${ }^{55}$ The ability of foreign investors to finance a venture using land as security is, therefore, also limited. But, assuming the secured obligation can be sold or otherwise disposed of to a Palauan citizen who may enforce the security interest against the obligor, mortgages are not necessarily without value to the foreign investor. $^{56}$

It is possible for non-citizens to lease real property in Palau, but only for a maximum of fifty years, inclusive of renewal options. ${ }^{57}$ Any lease agreement that violates this restriction is void; case law has held that to the extent a citizen is a co-lessee under such an agreement, it will remain in force as to the citizen. ${ }^{58}$ While legislation has been proposed that would extend the maximum lease term for non-citizens to ninety-nine years, it is uncertain whether it will come into force, particularly since the issue of lease terms has been scheduled as a referendum item for the 2008 Constitutional Convention. ${ }^{59}$

\section{OTHER ISSUES RELATING TO LAND OWNERSHIP}

A variety of historical factors further complicates the current state of land ownership in Palau. First, clans traditionally held most land, not individuals. ${ }^{60}$ Second, no written records existed of traditional land ownership or the metes and bounds of specific tracts. Third, even though individual ownership is

55. This prohibition is further strengthened by statute, which prohibits anyone other than a Palauan citizen or corporation wholly-owned by Palauan citizens from "holding title" to land. See 39 P.N.C. $\$ 301$. This is significant because the Palauan constitution only prohibits "acquisition." Thus, it would otherwise be possible for children having dual Palauan and foreign citizenships to acquire land as minors, abandon their Palauan citizenship, as required to by the constitution within three years of turning eighteen, yet lawfully retain ownership of Palauan land as a foreign national.

56. Title 39, section 604, of the Palauan National Code appears to anticipate this possibility in its definition of the term "Mortgagee," which includes the clear statement that "[a] noncitizen of the Republic may be a mortgagee under the provisions of this chapter, provided, however, that nothing in this chapter shall be construed to mean that a noncitizen mortgagee is entitled to hold title to real property in the Republic." 39 P.N.C. \$ 604(h).

57. 39 P.N.C. $\S 302$. There are a variety of ways in which foreign lessees may use the lease agreement to protect investments made under long-term land leases. For example, the lease can be drafted to require the Palauan lessor to compensate the lessee for improvements made on the leased property based on the value of the improvements at the expiration of the lease. Another option is to include a provision requiring the parties to negotiate in good faith the execution of a new lease within a few years of the expiration of the original fifty-year lease term. Other leases have been used that require the lessor to compensate the lessee for the value of improvements or enter into a new lease. The validity of such provisions has not been adjudicated.

58. Anastacio v. Haruo, 8 ROP Intrm. 128, 130 (2000).

59. Blaire Phillips, Land Leases Again Center of Controversy, PAC. MAG., May/June 2006 , at 8 .

60. THE WISDOM OF THE PAST, supra note 31 , at 45 . "Traditionally, although there was no formal system of land registration in Palau, there was a system of customary land ownership and control. Land was generally divided into public domain, controlled in most cases by the village council and the clan." Id. (citing LAND TENURE PATTERNS IN THE PACIFIC ISLANDS 296 (1958)). 
becoming more prevalent, the disposition of property upon a person's death can vary depending upon clan custom and clan decisions in individual cases. Fourth, the various foreign powers that administered Palau, particularly Japan, confiscated traditional lands and converted them to government use or turned them over to immigrants. Fifth, while Palauan government entities continue to use some of this land, Palau's Constitution requires that public lands be returned to the "original owners or their heirs," a process started by the Americans during the TTPI period. Often, this involves a factual determination taking place generations after the original owner was dispossessed. ${ }^{61}$ With the pending relocation of the nation's capital to the island of Babeldaob, much of the land in Koror will be vacated by government bodies. This will allow claims from the heirs of people dispossessed decades prior to be more easily processed. Moreover, this will prevent the property from being subject to eminent domain exercised by the Palau government. ${ }^{62}$ Sixth, while individual ownership of land has become widespread, Palau did not have a statute of frauds until 1977, meaning that many pieces of land may have been subject to multiple unrecorded oral conveyances. ${ }^{63}$ Finally, the massive disruption caused by World War II serves as another source of uncertainty as to historic title to land.

While the pre-war Japanese land survey and resulting tochi daicho is "presumed to be correct" by a court, it sometimes serves as little more than a starting point. ${ }^{64}$ This is in part because its creation was followed by a war and decades of unrecorded oral transactions. In addition, its limited utility in determining historical ownership in the states of Anguar or Pelelieu has already been noted. Furthermore, it is subject to claims that listings of individual ownership, as opposed to clan ownership, are erroneous. ${ }^{65}$ Finally, where the tochi daicho lists Japanese ownership, it is usually unhelpful in determining the historical title predating such ownership.

As a result of these and other factors, Palau's court system has been

61. CONST. OF THE REPUbLiC OF PALAU art. XIII, § 10.

62. In summer 2005 , the author was in Koror. He talked to a government official who said that the previous week he had people in his office marking out the dimensions of their claims in anticipation of the government's departure from the city due to the relocation of the capital.

63. See, e.g., Andreas v. Masami, 5 ROP Intrm. 205, 206 (1996). "The Statute of Frauds was enacted by the Palau Legislature in 1976 and first became effective as of April 1, 1977..." Id. See also Rengiil v. Ngirchokebai, 1 ROP Intrm. 197, 201 (1985) (citing Llecholch v. Blau, 6 TTR 525 (Palau)). "[A]n oral transfer [of land] is effective and there need be no recordation of an oral transfer." Id.

64. Ngiradilubech v. Timulch, 1 ROP Intrm. 625 (1989).

65. See, e.g., Arbedul v. Romei Lineage, 8 ROP Intrm. 30 (1999). See also Jeffrey S. Rasley, The Most Litigious People on Earth On Palau, Land Disputes Are a National Pastime, PAC. MAG., Dec. 2002, available at http://www.pacificislands.cc/pm122002/pmdefault.php?urlarticleid=0013 (last visited Oct. 30, 2006). "The Tochi Daicho was incomplete and parts of it were lost. In some cases, the Japanese had designated the chief or a strong member of the clan as registered owner, when, by tradition, the whole clan had rights to the land." Id. 
nearly overwhelmed with litigation over land title. Indeed, at least one observer called Palauans "the most litigious people on Earth." 66 This should not be surprising given the complicating factors described above, together with the overall context of a revolutionary change in notions of property from a traditional Palauan collective ownership system to a Western-style individual ownership model.

While the United States initially implemented a land registration program in the $1950 \mathrm{~s}$, the current registration process began in 1972. A special Land Court was created in 1996 to help facilitate the processing of land disputes. It is expected that resolution of pending and new cases will, at the very least, take several more years. ${ }^{67}$

In light of these circumstances, prospective investors contemplating any arrangement involving a lease or other use of land should conduct suitable due diligence regarding the status of title of the proposed site, as well as the claim of any putative owners. This includes ascertaining whether the land is owned individually or by a clan. If it is the latter, the inquiry proceeds to which clan member is entitled to enter into transactions involving the land on the clan's behalf. The Land Court maintains public files of all determinations it has made to date, together with any certificates of titles issued in connection with its proceedings. Under Palau's recording statute, all transfers of, or encumbrance upon, title to real estate or any interest therein, other than a lease or use right for a term not exceeding one year, are invalid unless recorded with Palau's Clerk of Courts. ${ }^{68}$

\section{FOREIGN INVESTMENT ACT - CERTIFICATION REQUIREMENTS}

The cornerstone of Palau's foreign investment regime is the Foreign Investment Act (FIA), which comprises sections 101-121 of title 28 of the Palauan National Code. The FIA specifies the procedures foreign investors must follow in Palau and contains a broad range of substantive limitations intended to limit foreign domination of the Palauan economy. In effect, it "prohibits the inflow of foreign capital investment into the country unless approved by the national government.",69 In this respect, Palau's foreign investment regime is quite different from those in other developing countries, where a principal goal of regulation may be limiting the ability of foreign capital to exit the country rather than enter it. ${ }^{70}$

66. See id. (emphasis added). This account gives a total of approximately 30,000 cases for a population of 18,000 . See id.

67. See id. See also THE WISDOM OF THE PAST, supra note 31 at 45-46. While I am not the one who will conduct it, Palau would seem to be a wonderful subject for study from a law and society perspective of a traditional "non-litigious" culture adopting and using a modern legal system.

68. 39 P.N.C. $\S \$ 401$.

69. Micr. Yachts Co. v. Palau Foreign Inv. Bd., 7 ROP Intrm. 128, 129 (1998).

70. In fact, because of the relative weakness of Palau's anti-money laundering regime, 
Foreign investment in Palau is subject to oversight from the Foreign Investment Board (FIB). The FIB is an executive branch body. It consists of seven members appointed by the president with the advice and consent of the Senate. ${ }^{71}$ All non-Palauan citizens seeking to do business in the country must first obtain a foreign investment approval certificate (FIAC) from the FIB. This requirement applies in three scenarios:

(a) non-citizens wishing to directly or indirectly "carry on a business enterprise" in the ROP, ${ }^{72}$

(b) business enterprises in Palau that are wholly-owned by citizens and in which a non-citizen wishes to acquire an ownership interest or make an investment (other than lending) ${ }^{73}$ and

(c) any grantee of an existing FIAC seeking to engage in any business that it does not cover. ${ }^{74}$

Two important exceptions to FIA certification requirements exist:

(a) companies doing business or making an investment pursuant to a contract with the national government of Palau, and

(b) any entity engaged exclusively in the practice of law or medicine. ${ }^{75}$

Some definitions are necessary before proceeding. "Non-citizen" means any person, natural or legal, who is not a citizen of the ROP, and includes any business enterprise in which a non-citizen owns an interest. ${ }^{76}$ Thus, even Palauan majority-owned businesses are subject to certification requirements. "Carry[ing] on a business" is defined as "engaging in any kind of business enterprise, profession or trade, as an owner or part-owner, for the purpose, in whole or in part, of commercial gain or profit."77 "Business enterprise" is defined as "any sole proprietorship, partnership, corporation, trust, joint venture, association, or any other form of business organization established in the Republic for the purpose of carrying on a business."

foreign banks have on occasion refused to honor wire transfers originating from Palau. Shuster, supra note 50, at 121 .

71. 28 P.N.C. $\S 104$.

72. 28 P.N.C. $\S 103$ (a).

73. 28 P.N.C. $\$ 103$ (b).

74. 28 P.N.C. $\$ 103(\mathrm{c})$.

75. The exclusion for investments pursuant to a government contract is provided for specifically in paragraph (d) of section 103, which sets forth the substantive certification requirement, as well as in the exclusions to the section 102(c) definition of Business Enterprise discussed infra, note 78. The exclusion for medical and legal practices is contained only in the section 102(c) definition.

76. 28 P.N.C. $\S 102(1)$.

77. 28 P.N.C. $\$ 102(d)$.

78. 28 P.N.C. $\$ 102$ (c) (emphasis added). The definition also includes an exception for non-profit entities engaged in non-political charitable, religious, scientific or other similar activities. 
The requirement that a business enterprise be "established in the Republic" is key; it has been interpreted as excluding foreign business entities that conduct transitory business activities in Palau without establishing a significant long-term presence. In Tulmau v. R.P. Calma \& Co., the appellate division of the Supreme Court of Palau determined that a Philippine accounting firm which did not maintain a presence in the ROP but which had conducted audits of two Palauan companies was not in violation of FIA certification requirements. $^{79}$ The accounting firm's activities included both sending employees to Palau and paying Palauan gross revenue taxes on the revenue generated in the country. Holding that "[s]ome degree of permanency must exist before a business can be deemed "established," the court in Tulmau interpreted the FIA certification requirements as being triggered only when a non-citizen carries on a business in the ROP, and the foreigner is " established in the Republic for the purpose of carrying on a business." business trips to Palau and other limited activities not involving a long term presence should not trigger the certification requirement.

While the FIA does not contain provisions dealing with the transfer of FIACs, the FIB subjects the issuance of FIACs to conditions, including that they are non-transferable either directly or through a change in ownership of the entity to which the FIAC is issued. ${ }^{81}$ While FIA case law is limited, the ROP courts have adopted a substance-over-form approach toward FIA issues. Thus, attempts to subvert the substantive requirements of the law are likely to be invalidated. According to one Supreme Court ruling on the FIA:

[T]he statute is drafted so that a non-citizen who decides to invest foreign capital in Palau must obtain a foreign investment certificate, and it does not matter whether this investment occurs through sale of stock, is filtered through a series of corporations, or occurs via partnership agreements, purported "employment" contracts, creative business "leases," or any other structural legerdemain. ${ }^{82}$

An FIAC will only be issued for businesses involving an investment of not less than $\$ 500,000$ or which maintains a work force that is comprised of at least twenty percent Palauan nationals. ${ }^{83}$ The FIB evaluates FIAC applications

79. Tulmau v. R.P. Calma \& Co., 6 ROP Intrm. 54 (1997).

80. Id. at 56-57 (citing Tulmau v. R.P. Calma \& Co., 3 ROP Intrm. 205 (1992)).

81. While it is not uncommon in project financing-type transactions for lenders to receive a collateral assignment of licenses and permits as supplemental security, such a mechanism seems unlikely to provide tangible benefits in the case of a non-transferable FIAC.

82. Micr. Yachts Co. v. Palau Foreign Inv. Bd., 7 ROP Intrm. 128, 130 (1998). Those tempted to believe that Palau's judiciary might be fooled by particularly complex transaction structures should know that one of its members, Associate Justice Larry Miller, was once an attorney at a major Wall Street law firm.

83. 28 P.N.C. § 106. 
based on a variety of criteria, including benefits to the ROP, transfer of skills to Palauan nationals, and the likelihood that similar activities being carried on by citizens will be impacted. Moreover, the FIB requires the submission of an investment analysis, plans for training programs and management participation by Palauan citizens, existing and proposed wage and benefit programs, and other detailed information. $^{84}$

When the FIB grants an FIAC, it must also specify a number of terms and conditions applicable to it including: the scope of the business activity covered, the scope of utilization of raw materials, the scope of services and materials provided by citizens, the participation by citizens in management, training programs for citizens for the transfer of managerial and technical skills, the duration of the permission granted by the FLAC, and any guarantees that may be required from non-citizens. ${ }^{85}$

FIAC issuance may also be conditioned upon the maintenance of a security deposit in a bank in Palau, the purpose of which is to "safeguard the interest of persons doing business with [the] grantee." ${ }^{, 86}$ With some exceptions for agricultural or aquacultural workers, businesses operating under an FIAC are also required to pay a minimum wage, "not less than the minimum wage paid to national government employees." such periodic reporting requirements as may be imposed by FIB regulations. ${ }^{88}$

When rejecting an application the FIB must record the reason for doing so "with as much detail as possible." 89 Aggrieved applicants may request that the FIB reconsider a rejected application. While its determinations are final, the FIA anticipates that judicial remedies may also be available in some cases. ${ }^{90}$

A grantee may request an amendment of an existing FIAC. The FIB may amend an FIAC as long as the amendment would not permit a business activity that is substantially different from or unrelated to that covered by the original FIAC. ${ }^{91}$ In such cases, an entirely new application is necessary. ${ }^{92}$

84. 28 P.N.C. $\S \S 107-108$. One fact that may not be considered is whether a foreignowned business will provide better service than a local one. In Masang v. Dengkol, 9 ROP 243 (Tr. Div. 2001), the Supreme Court ruled that it was an abuse of discretion for the FIB to have granted a foreign investor an FIAC for the establishment of a cellular phone business on the basis that, in the view of at least one FIB member, the foreign company would provide better service than the existing Palauan-owned cellular provider. The Court determined that " $[i] f$ that was the test, there would be no need for a Foreign Investment Board, because any foreign investor who was not providing better service than the local business would not be much competition." Id. at 247.

85. 28 P.N.C. $\$ \S 108(\mathrm{k})(1-7)$.

86. 28 P.N.C. $\$ 108(k)(8)$.

87. 28 P.N.C. $\$ 108(\mathbf{k})(9)$.

88. 28 P.N.C. $\$ 111$.

89. 28 P.N.C. $\$ \S 108(k)(10)$.

90. See 28 P.N.C. \$ 109.

91. 28 P.N.C. $\S 110$.

92. Id. 


\section{FOREIGN INVESTMENT ACT - LOCAL OWNERSHIP REQUIREMENTS}

In addition to the certification requirement described above, the FIA also contains a provision that further limits foreign participation in certain areas of business. Since the drafting is somewhat complex and creates different categories, it warrants quoting almost in full, but with some changes to facilitate understanding. Under section 105 of the FIA: "[ $t]$ he following business activities are reserved exclusively for citizens and business enterprises in which citizens have an ownership interest and shall not be permitted to be undertaken by any business enterprise in which no citizen has an ownership interest.."93

The statute lists businesses to which this restriction applies:

(a) wholesale or retail sale of goods.

(b) all land transportation including bus services, taxi services, and car rentals.

(c) handicraft and gift shops; provided, however, that handicraft or gift shops located on the premises of hotels or at the Palau International Airport shall be exempt from the prohibition of this section.

(d) bakeries.

(e) bar services not associated and contained within a restaurant or hotel complex. For purposes of this subsection, hotel complex means any lodging facility having at least 50 rooms for the accommodation of guests.

(f) tour guides, fishing guides, diving guides, and any other form of water transportation services.

(g) travel and tour agencies.

(h) operations manufacturing products being produced by wholly Palauan-owned manufacturing enterprises.

(i) equipment rentals for both land and water within the Republic, including equipment for purpose of tourism.

(j) commercial fishing for other than highly migratory species. ${ }^{94}$

(k) any such other business as the [FIB] may determine. ${ }^{95}$

As is probably evident from this list, section 105 infers that many of the business opportunities in which foreign investors are likely to be interestedincluding many tourism-related opportunities-cannot be conducted without involving a Palauan partner.

Furthermore, section 105 contains a proviso specifying that the types of

93. 28 P.N.C. § 105 (emphasis added).

94. Note that the characterization of fish species as "highly migratory" is of constitutional significance; Palau's constitution grants to each state "exclusive ownership of all living and non-living resources, except highly migratory fish, from the land to twelve (12) nautical miles seaward from the traditional baseline." CONST. OF THE REPUBLIC OF PALAU art. I, \& 2 (emphasis added).

95. 28 P.N.C. §§ $105(\mathrm{a}-\mathrm{k})$. 
businesses listed in subsections (a), (b), (f), (g) and (j) "are reserved exclusively for citizens." 96 Thus, section 105 creates two special categories of business: (1) those in which foreigners can participate, as long as a Palauan has an ownership interest in the business and the FIAC requirements of the FIA are followed, and (2) those in which foreigners cannot directly participate even with a Palauan partner.

The business category in subsection (h) may be of concern. The FIB's ability to use the FLAC granting process to impose requirements upon noncitizen investors regarding management participation by citizens and the transfer of knowledge and skills to Palauans may present an additional obstacle for investors. A foreign investor who creates a new and wholly-owned manufacturing operation in Palau under an FIAC with a finite term may discover that they have enabled a local competition, rendering future renewals of the FIAC potentially problematic. ${ }^{97}$

\section{FOREIGN INVESTMENT ACT - SANCTIONS}

The FIB may modify, suspend, or revoke an FIAC in a variety of situations. These situations include: the determination that the FIAC was obtained based on fraudulent information or corruption, the grantee violating any law of the ROP or any term or condition applicable to the FIAC, or the grantee engaging in any business activity or making any investment outside the scope of the granted FIAC. ${ }^{98}$ Non-citizens who violate the FIA's certification requirements may also be subject to imprisonment for up to one year and/or fines of up to $\$ 25,000 .^{99}$ Any person, regardless of citizenship, who aids and abets a violator is subject to similar penalties. ${ }^{100}$

Foreign investors should also take note of section 120 of the FIA, which provides that "[a]ny citizen or resident of the Republic of Palau ... shall have standing and capacity to bring suit to enforce the provisions of this chapter as a private Attorney General." 101 In effect, anyone in Palau has standing to sue under the FIA for alleged violations. This provision both limits the FIB's discretion and makes it difficult to expect that an uncertificated or otherwise non-compliant investment will simply escape attention. ${ }^{102}$

96. Id. (emphasis added). With respect to subsection (j), farm-raised fish and maricultured species are excluded from the Palauans-only provision.

97. A transitional provision is included that allows non-citizens holding permits for businesses covered by section 105 to continue engaging in such businesses, whether solely or jointly with citizens, but only for the current terms of such permits.

98. 28 P.N.C. \& 112.

99. 28 P.N.C. $\$ 113$.

100. 28 P.N.C. § 114 .

101. 28 P.N.C. \& 120.

102. Indeed, a private attorney general provision was added to an earlier version of the FIA due to the legislature's concern that the government was not enforcing it. Tulmau v. R.P. Calma \& Co., 3 ROP Intrm. 205, 208 (1992). Tulmau involved a separation of powers challenge to the private attorney general provision of the FIA, resulting in a finding by the appellate division of 


\section{ClOSING REMARKS}

The FIA effectively creates three different overlapping categories of foreign investment to which its requirements apply. First, all foreign investments must be conducted under an FIAC, which may be subject to a variety of requirements, including a minimum threshold of $\$ 500,000$ or twenty percent employment of Palauans. Second, businesses included in the nonexclusive categories specified in section 105 may only be engaged in by enterprises that are at least partially Palauan-owned. Third, the categories of business specified in section 105 are reserved exclusively for citizens and are effectively closed to foreign investors.

Given the restrictions imposed upon the ownership and use of land by non-citizens, as well as the importance of clan affiliation and other unique characteristics of Palau's small, close-knit society, a citizen partner or shareholder will often be desirable even when not required under the FIA. Here, as in any foreign investment, careful due diligence should be conducted regarding the prospective partner, as well as the history and legal status of any land or other real property the partner proposes to commit or otherwise make available to a business venture. For example, one common scenario that requires special care and diligence, not to mention delicacy in broaching the issues, occurs when a non-Palauan citizen resident manages a business or land on behalf of a citizen, spouse, or other family member. In such scenarios the non-citizen may indeed have more knowledge and understanding of the business or property. Even though the citizen's participation may be passive, his or her intent to cooperate in the venture or proposed use of land should be confirmed and, if possible, documented.

Financial institutions providing loan financing to ventures in Palau also need to understand that their ability to obtain and enforce security interests may be limited. Debtor-in-possession and other similar managerial arrangements may not be possible in the event of business failure due to the non-transferable nature of FIACs. For significant loans or other investments, offshore security arrangements may be an integral component simply because of the limitations imposed upon collateral enforcement by the FIA and the constitution.

The constitutional and other prohibitions imposed upon the participation by non-citizens in Palau's economy may seem anachronistic in the 21 st century climate of free trade and globalization. It should be remembered, however, that in terms of population and economic size, Palau is smaller than many multinational companies. Furthermore, the country is already subject to a high degree of political and economic domination by the United States and other regional powers. Thus, without the protections provided by Palau's constitution and other laws, it would be easy for the Palauan people to become bit-players in their own economy, as has seemingly been the fate of people in many other developing countries. ${ }^{103}$ From this perspective, Palau may provide

103. This may be happening anyway; according to one report, three quarters of the labor 
a useful reference model for small states seeking to preserve their unique culture in the modern interconnected world.

As noted at the outset, one of Palau's greatest resources is its tremendous natural beauty. This beauty alone, however, is valueless unless people and leaders have the determination and foresight to establish a legal regime that enhances the protection of that tremendous resource. Foreign investment will hopefully continue and increase in a framework that makes the goals of environmental protection, cultural autonomy, and economic development simultaneously achievable. 